\title{
EFFECTS OF MECHANICAL TRANSPLANTING TECHNIQUE ON PRODUCTIVITY FOR G86 COTTON VARIETY
}

\section{A. Hassan*; M. A. Basiouny** and A. E. El-Yamani**}

\begin{abstract}
Experimental study was carried out to evaluate the performance of mechanical transplanting technique using cotton variety G86. The transplanting experiments were conducted using a Holland type transplanter to evaluate the effect of four forward speeds $(1.43,1.77,2.05$ and $2.44 \mathrm{~km} / \mathrm{h})$, three hill spacing $(0.15,0.2$ and $0.25 \mathrm{~m})$ and four planting depths (5, 7, 10 and 12cm) compared with manual transplanting. Both mechanical and manual transplanting methods were undertaken at the same time. Effective field capacity, field efficiency, seedling miss index, seedlings multiples index, quality of feed index, amount of seedling rate and plant yield traits (h. first fruit, seed cotton yield/fed, lint cotton yield/fed, boll weight, lint percent and seed index) were determined. Results illustrated that increasing planting forward speed increased actual field capacity, affective field efficiency, seedling miss index, the quality of feed index and criterion function cost. While, seedling multiple index, total productivity and losses in productivity were decreased. Also results indicated that, maximum of effective field capacity; field efficiency and productivity were $0.711 \mathrm{fed} / \mathrm{h}, 80.1 \%$ and $7.61 \mathrm{kantar} / \mathrm{fed}$, respectively. While minimum of seedling miss index, seedling multiple index and quality of feed index were $1.7 \%, 1.3 \%$ and $89.9 \%$ respectively. The optimum operational conditions of machine transplanting were at forward speed $1.77 \mathrm{~km} / \mathrm{h}$, hill spacing of $0.15 \mathrm{~m}$ and planting depth of $7 \mathrm{~cm}$ at this condition total productivity was 7.41 kentar/fed and total losses in productivity was 0.226 kentar/fed.
\end{abstract}

Keywords: cotton transplanted, seedling miss index, the seedlings multiples index, feed index, the cotton traits, fiber properties.

*Researcher \& **Senior researcher in Agric. Eng. Res. Inst., ARC, Giza, Egypt. 


\section{INTRODUCTION}

owing date respect an important part in productivity and properties of Egyptian cotton. Late sowing in May has an adverse effect on yield and its components. Cotton seedlings are planted in order to shorten the growing season to reduce the cost of production and the possibility of cultivation of cotton after winter crops in the same space as well as providing cottonseed and maintain the purity of the product and the production of hybrid cotton and reduce the proportion of early and late injuries. Seedling transplanting can significantly increase yield, reduce seeding rates and improve crop establishment by eliminating harmful environmental effects before transplanting. For cotton, the duration of growth and development was extended in comparison with normal planting methods in northern Shandong, China (Dong et al., 2005). Seif-El-Nasr et al. (1996) showed that transplanting, not only reduces the use of fertilizer, but also increases the yield compared to direct seed planting and also transplanting after wheat harvest. Rawdan (1988) reported that transplanting produced lower yield than direct seed sowing. Using the transplanting system in cotton is important for breeding programs and farmers, because it helps the breeder using the mutation which gives low germination ratio for seeds by using direct seed sowing in field. Using the system is very important for the farmers because it helps to produce the cotton after the complete season of winter crops (wheat, clover and bean) as well as it gave us decrease the cost for feddan. Abbas (1981) and Imam (1991) observed that seed cotton yield per plant and per feddan insignificantly increased by transplanting cotton as compared to seed planting. El-Sayed (1992) studied the effect of transplanting on growth and yield of cotton. He found that the first node carrying fruiting branches was high for direct sowing and low for transplanting method. Waddle (1993) reported that, using transplanting system was more efficiency. Transplanting technique decreased the crown then significantly when the root-tip then did not affect. Abou Zeid et al. (1995) found that, the lint percent and seed index had higher values in transplanting than the direct sowing. Salama et al. (1995) said that there is a significant increase in boll weight and number of bolls per plant under mechanical transplanting compared with the manual transplanting. Herb 
et al. (1993) compared the mechanical transplanting and manual method. $\mathrm{He}$ found that, the percentage of mechanical damage was 5\% for transplanters. Manual transplanting gave highest population per unit area. Disc pocket arrangement transplanter gave the lowest percentage of defective hills after weeks from transplanting. Capacity of $0.24 \mathrm{fed} / \mathrm{h}$ and field efficiency of 56\% were the same for all transplanters. El-Fowal (1996) concluded that, with using transplanters at the working forward speeds of $1.22,1.26$ and $1.51,1.44 \mathrm{~km} / \mathrm{h}$ recorded slippage of $16.49,16.84$ and 10.82 and $11.85 \%$. Field efficiencies of 75.64, 74.72 and 58.11, $59.64 \%$ for 4-row and 6-row riding transplanter during the two seasons, respectively. Hamed et al. (1993) found that seedling damage in planting and feeding losses increased due to increasing transplanter forward speed. Transplanting can significantly increase yield, reduce seeding rates and improve crop establishment by eliminating harmful environmental effects before transplanting for cotton, the duration of growth and development was extended in comparison with normal planting methods (Dong et al., 2005). Such advantages for cotton transplanting have also been demonstrated in other countries (Sherif et al., 1995; El-Sahrigi et al., 2001; Greer et al., 2003; Karve, 2003 and Sales et al., 2006). Hassan et al., (2006) found that all the studied traits fiber length, uniformity ratio, micronaire reading and fiber strength showed highly significant difference mean squares for genotypes, environments and the interaction between them. The objective of this study was to evaluate the performance of small cotton transplanter and to compare its performance with manual transplanting method.

\section{MATERIALS AND METHODS}

The present study was conducted at Sakha Agricultural Research Station, Kafrelsheikh Governorate in 2013 to evaluate the field performance of small transplanter (Holland type) under local conditions comparing with manual transplanting method. The field was prepared using chisel plough twice and hydraulic scraper to level and creates an ultimate smooth surface. Yanemar tractor $60 \mathrm{hp}(44.12 \mathrm{~kW})$ was used to mount the chisel plow, scraper and cotton seed planting transplanting machine. All agricultural operations as fertilization, irrigation and pest control were 
performed in a similar manner to that commonly practiced at the Egyptian farms. The mechanical analysis data of the experimental soil are shown in Table 1. Used cotton variety Giza 86 was sown planted in paper pot sets in April 2013 then transport to the field in May 2013 after 30 days from planting day. The spacing between rows was kept fixed at $0.76 \mathrm{~m}$.

Table 1: Mechanical analysis of soil before carrying out plugging operation.

\begin{tabular}{|c|c|c|c|c|c|c|c|c|c|}
\hline \multirow{2}{*}{$\begin{array}{c}\text { Sample } \\
\text { depth } \\
(\mathrm{cm})\end{array}$} & \multicolumn{2}{|c|}{ Particle size distribution, $\%$} & \multirow{2}{*}{ FC } & WP & Bd & WHC & Texture \\
\cline { 2 - 9 } & sand & Sand & Silt & Clay & $(\%)$ & $(\%)$ & $\left(\mathrm{g} / \mathrm{cm}^{3}\right)$ & $(\mathrm{mm} / \mathrm{m})$ & class \\
\hline $0-30$ & 3.3 & 25.2 & 21.2 & 50.3 & 29.0 & 17.0 & 1.3 & 158.0 & CL \\
\hline $30-60$ & 3.4 & 22.6 & 22.5 & 51.5 & 30.0 & 19.0 & 1.4 & 156.0 & CL \\
\hline $60-100$ & 4.0 & 20.5 & 26.0 & 49.5 & 28.0 & 18.0 & 1.5 & 153.0 & CL \\
\hline
\end{tabular}

$* \mathrm{FC}=$ field capacity; $\mathrm{WP}=$ welting point, $\mathrm{FC}$ and $\mathrm{WP}$ were determined as percentage by weight; $\mathrm{Bd}=$ bulk density; $\mathrm{WHC}=$ water holding capacity and $\mathrm{CL}=$ clay loam (Soil Dept. Lab ).

\section{Holland transplanter:}

The available transplanter is semi-automatic transplanter made up of two units and intended for transplanting of ball seedlings on well-prepared fields, as shown in Fig. 1. The general specifications of Holland type transplanter are presented in Table 2. The basic parts of the equipment are: furrow opener, pocket for plants, packing wheels and plant boxes. These parts are mounted onto a common frame attached to the three point hitch toolbar. Plants are placed manually on to the transplanting pockets that consist of two rubber plates in order to hold the plant. The rubber plates are opened and closed by using a special spring mechanism. The closing of the rubber occur as soon as the pocket enters two guide plates which compress the spring. When the pocket passes from the guide plates, the spring pressure is released, loosening the rubber plates and releasing the plant to slip from pocket and remain it in the soil. 


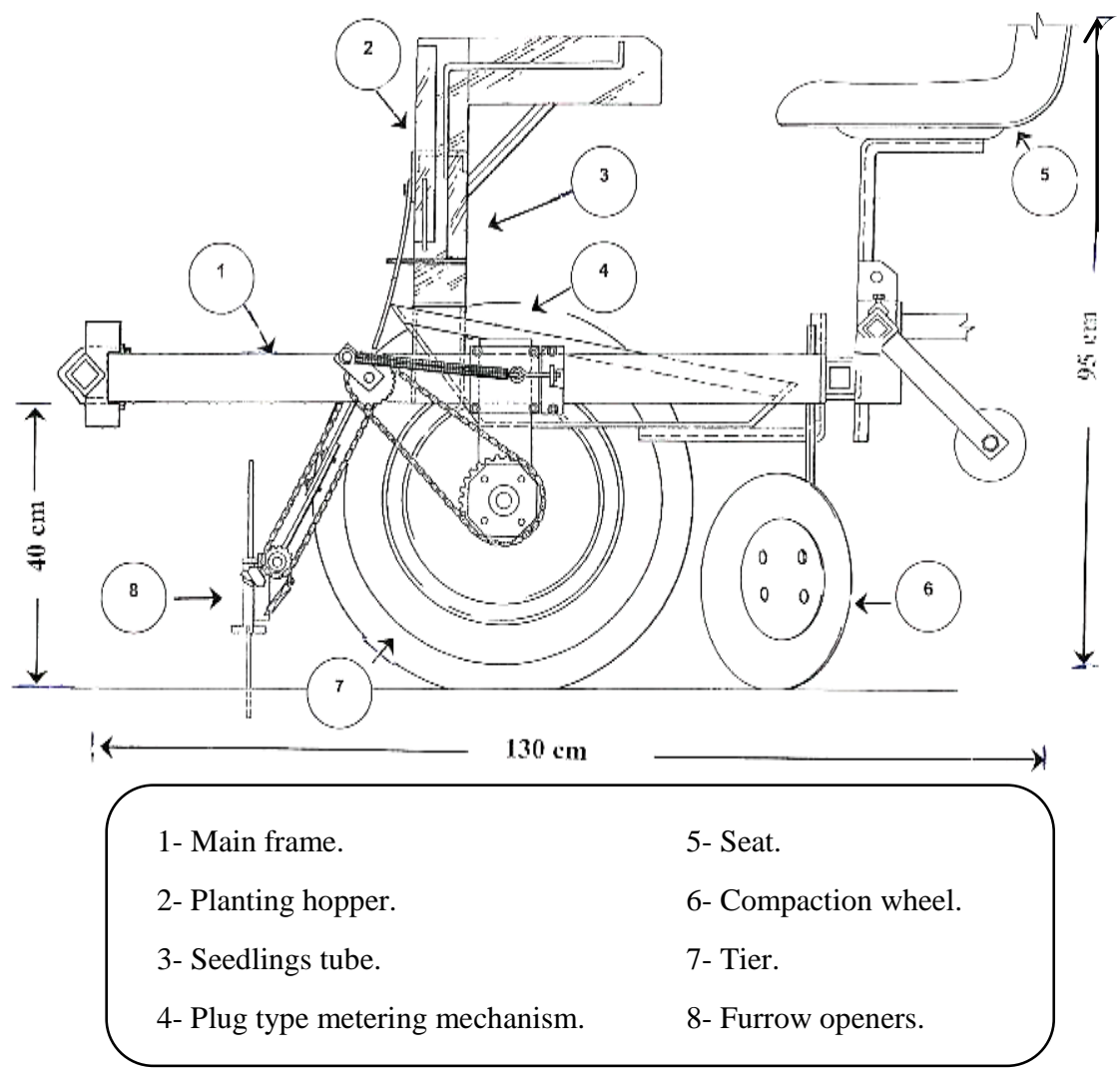

Fig. 1: A geometrical drawing of a semi-automatic transplanted (Holland type).

Table 2: Specification of the Holland transplanter.

\begin{tabular}{|l|l|}
\hline \multicolumn{1}{|c|}{ Item } & \multicolumn{1}{|c|}{ Specification } \\
\hline Manufacture & U.S.A \\
Model & Holland type 1700 \\
Total length, m & 1.30 \\
Total width, m & 2.45 \\
Total height, m & 0.95 \\
Total mass, kg & 150 \\
Hitching type & 3 point \\
Number of units & 2 \\
\hline
\end{tabular}




\section{Investigated variables:}

The present study was carried out in about two feddans for testing transplanter machine and to evaluate the effect of forward speed of 1.43, $1.77,2.05$ and $2.44 \mathrm{~km} / \mathrm{h}$, hill spacing of $0.15,0.20$ and $0.25 \mathrm{~m}$ and planting depth of 5,7,10 and $12 \mathrm{~cm}$ compared with manual transplanting at the time of nursery planting as well as at the time of transplanting seedling on effective field capacity, field efficiency, seedling miss index, seedlings multiples index, the quality of feed index, yield traits. Also. physical and mechanical fiber quality properties was determined from each treatment, three replications were used.

\section{Measurements:}

Effective field capacity ( $E F C$ ) and field efficiency ( $F E$ ):

They were calculated according to the following equations:

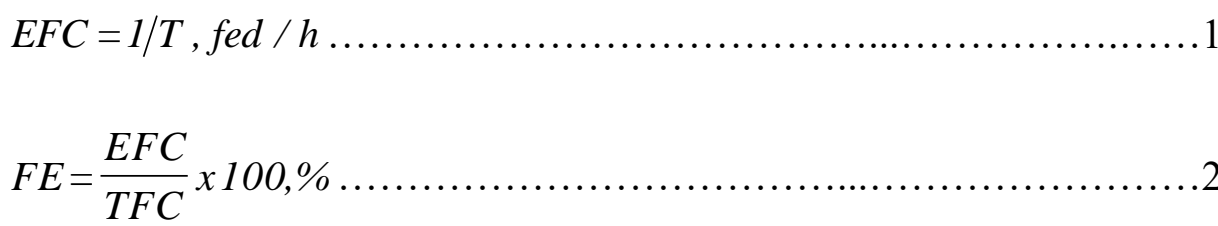

Where:

$T \quad$ Effective planting time, $\mathrm{h}$.

TFC Theoretical field capacity, fed/h.

Seedling Miss Index ( $\mathrm{Sm}$ ), \%:

It was estimated for each treatment by counting the number of location that have no seedlings and counting the total number of the seedling in each treatment. Then, the percentage of miss index can be calculated as follows (Srivastava, 1995):

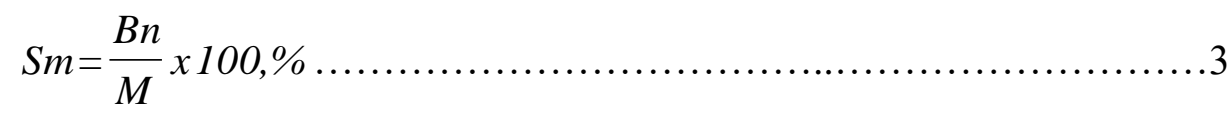

Where:

$B n$ the number of seed location that have no seedling.

$M \quad$ the total number of the used seedling.

The seedlings multiples index, (

It was estimated for each treatment by counting the number of holes that have more than one seedling and counting the number of the total seedling in each treatment. Then the percentage of seedlings multiples index can be calculated as follows: 


$$
\text { Smu }=\frac{A n}{M} \times 100, \%
$$

Where:

An the number of holes that have more than one seedlings.

\section{The quality of feed index ( $U H)$, \%:}

It was estimated by calculating the seed miss index and the seed multiples index. Then the percentage of the quality of feed index in row can be calculated as follows:

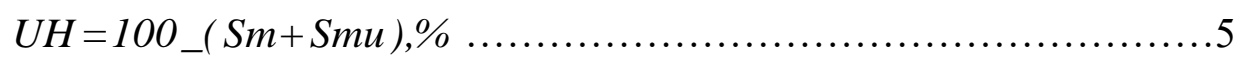

\section{Productivity, kentar/fed:}

The cotton crop yield was determined for manual and mechanical transplanting methods, A number of samples a long the row were taken from different locations for each treatment at random, and then weighed and integrated to determine the average yield of cotton per feddan.

\section{The traits studied were:}

7 Position of the first fruiting node (F.F.N.).

$\checkmark$ Seed cotton yield: obtained as weight of seed cotton yield $(\mathrm{kg})$ per plot and converted to kentar per feddan (kentar $=157.5 \mathrm{~kg})$.

$\checkmark$ Lint yield: calculated as follows: (weight of seed cotton yield per feddan $x$ lint percentage).

A sample of 50 bolls was harvested at randomly from each plot and was used to obtain plot mean values for:

4 Boll weight in gram: the average weight of 50 bolls in gram.

$\checkmark$ Lint percentage (L.P.): ratio of lint weight to seed cotton weight in the sample expressed as percentage.

4 Seed index (S.I): weight of 100 seeds in grams.

0 Lint index (L.I): weight of lint produced by 100 seeds in grams, LI = $\{($ SI x LP $) /(100-$ LP $)\}$

\section{The physical and mechanical of fiber properties:}

The physical and mechanical fiber properties were determined at fiber testing laboratory, CRI, ARC, Giza. As follows:

4 Fiber length: The digital fibrograph (model, 630) used to determine 2.5 and 5\% span fiber length according to May and Bridges, 1995.

$\checkmark$ Uniformity ratio: Determined by using the following formula: 
Uniformity ratio $=\frac{50 \% \text { span fiber length }}{2.5 \% \text { span fiber length }} \times 100, \% \ldots \ldots \ldots \ldots \ldots \ldots \ldots$

Where, it was expressed on uniformity quantity between short and long fiber length.

4 Lint Color: HVI 9000 according to ASTM (D-1684-96) estimated lint color (reflectance Rd, \% and yellowness $+b$ )

4 Fibers strength and elongation: Measured by using stelometer instrument at fiber testing laboratory, CRI, ARC according to (ASTM, designated D-1445-75, 1984). Where, this instrument give elongation reading and cotton strength can be determined by using the following formula:

Strength for lengthunit $=\frac{(1.5) \text { cutting mass }}{\text { Massof sample }} \times 100, g /$ tex $\ldots \ldots \ldots \ldots . . .7$

\section{RESULTS AND DISCUSSION}

\section{A- Performance of transplanting machine:}

Preliminary experiments have been made during 2013 to determine the optimal conditions for operation of cotton transplanting machine and measurements were as follows:

\section{Effective field capacity and field efficiency:}

Results of the effective field capacity and field efficiency as shown in Fig. 2 illustrate that, effective field capacity increased as forward speed, hill spacing and planting depth increased. Results noticed also that, maximum effective field capacity of $0.711 \mathrm{fed} / \mathrm{h}$ was recorded at forward speed of $2.44 \mathrm{~km} / \mathrm{h}$, hill spacing of $0.25 \mathrm{~m}$ and planting depth of $5 \mathrm{~cm}$. While, minimum effective field capacity of $0.40 \mathrm{fed} / \mathrm{h}$ was recorded at forward speed of $1.43 \mathrm{~km} / \mathrm{h}$, hill spacing of $0.15 \mathrm{~cm}$ and planting depth of $12 \mathrm{~cm}$. On the other hand, field efficiency was decreased with increasing forward speed and hill spacing while, it was increased with increasing hill spacing. Also, results showed that, maximum field efficiency of $80.1 \%$ was recorded at forward speed of $1.43 \mathrm{~km} / \mathrm{h}$, hill spacing of $0.25 \mathrm{~m}$ and planting depth of $5 \mathrm{~cm}$. While, minimum field efficiency of $56.6 \%$ was recorded at forward speed of $2.44 \mathrm{~km} / \mathrm{h}$, hill spacing of $0.15 \mathrm{~m}$ and planting depth of $12 \mathrm{~cm}$. 


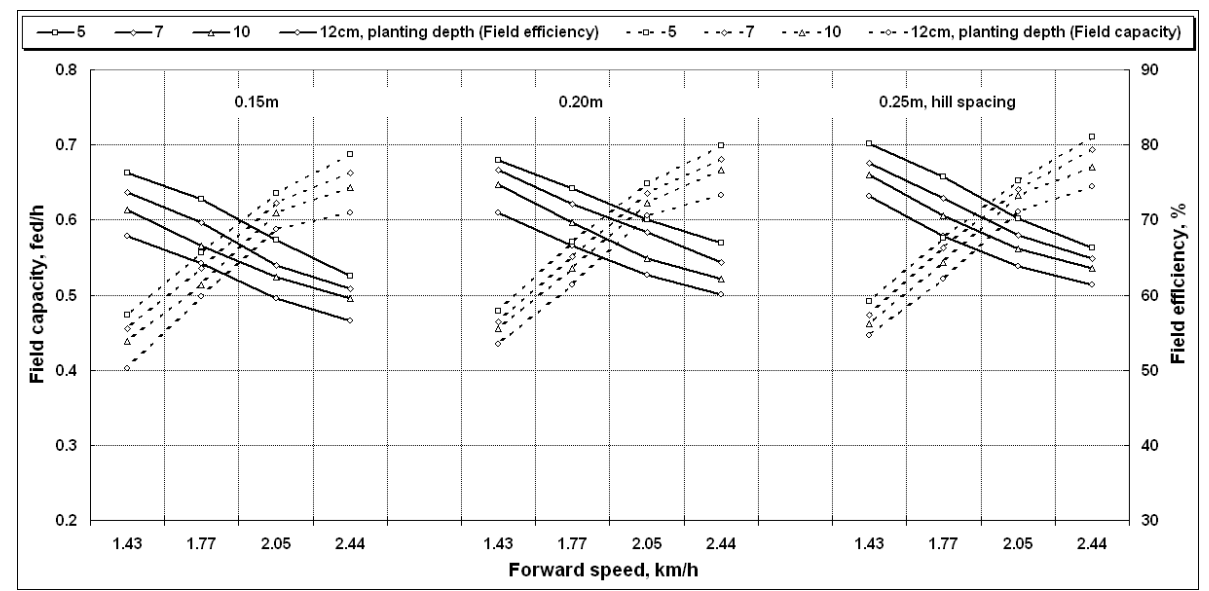

Fig. 2: Effects of forward speed, hill spacing and planting depth on effective field capacity and field efficiency.

\section{Seedling miss index:}

Results found that, increasing forward speed and planting depth led to decrease seedling miss index while increasing hill spacing led to increase seedling miss index as shown in Fig. 3. Such as, increasing forward speed from 1.43 to $2.44 \mathrm{~km} / \mathrm{h}$ at constancy hill spacing of $0.15 \mathrm{~m}$ and planting depth of $5 \mathrm{~cm}$, seedling miss index was decreased from 2.9 to $2.6 \%$. Also, with increasing planting depth from 5 to $12 \mathrm{~cm}$ at forward speed of $1.43 \mathrm{~km} / \mathrm{h}$ and hill spacing of $0.15 \mathrm{~m}$, seedling miss index was decreased from 2.9 to $2.4 \%$. While, with increasing hill spacing from 0.15 to $0.25 \mathrm{~m}$ at forward speed of $1.43 \mathrm{~km} / \mathrm{h}$ and planting depth of $5 \mathrm{~cm}$, seedling miss index was increased from 2.9 to $3.91 \%$. Results revealed also that, minimum seedling miss index of $1.7 \%$ was recorded at forward speed of $2.44 \mathrm{~km} / \mathrm{h}$, hill spacing of $0.15 \mathrm{~m}$ and planting depth of $12 \mathrm{~cm}$.

\section{Seedling multiple index:}

Results indicated that, seedling multiple index was decreased with increasing forward speed, hill spacing and planting depth as shown in Fig. 4. For instance, with increasing forward speed from 1.43 to $2.44 \mathrm{~km} / \mathrm{h}$ at hill spacing of $0.15 \mathrm{~m}$ and planting depth of $5 \mathrm{~cm}$, seedling multiple index was increased from 2.4 to $4.3 \%$. Also, seedling multiple index was decreased from 2.4 to $1.9 \%$ with increasing hill spacing from 0.15 to $0.25 \mathrm{~m}$ at forward speed of $1.43 \mathrm{~km} / \mathrm{h}$ and planting depth of $5 \mathrm{~cm}$. And it 
was decreased also from 2.4 to $1.8 \%$ with increasing planting depth from 5 to $12 \mathrm{~cm}$ at forward speed of $1.43 \mathrm{~km} / \mathrm{h}$ and hill spacing of $0.15 \mathrm{~m}$. Results noticed that also, minimum seedling multiple index of $1.3 \%$ was recorded at forward speed of $1.43 \mathrm{~km} / \mathrm{h}$, hill spacing of $0.25 \mathrm{~m}$ and planting depth of $12 \mathrm{~cm}$.

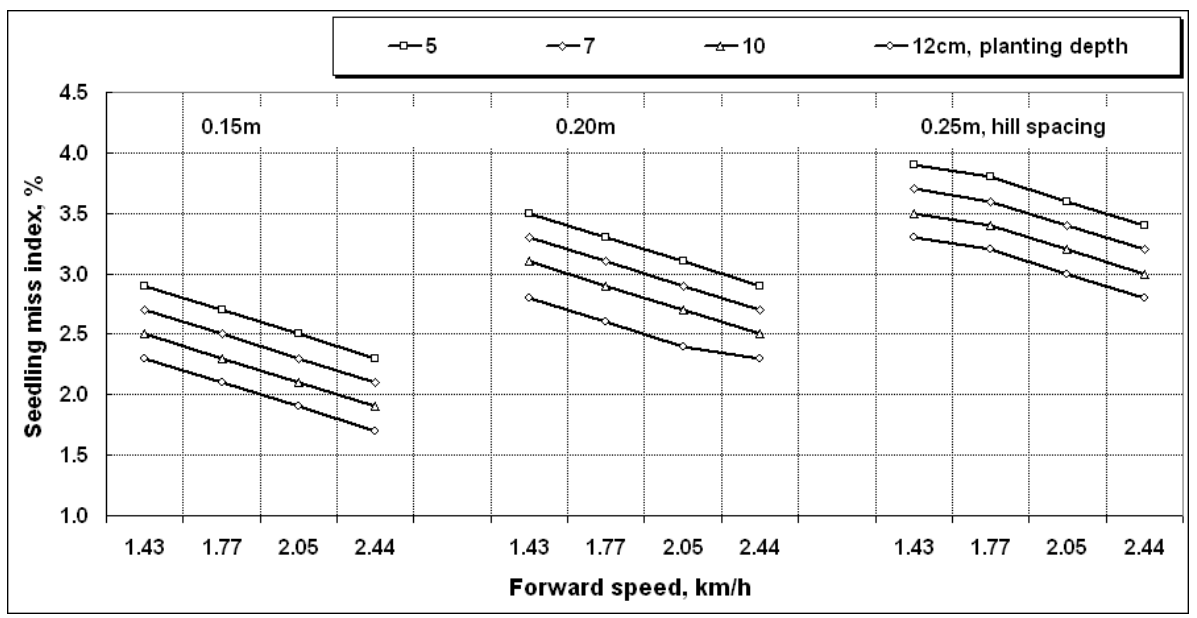

Fig. 3: Effects of forward speed, hill spacing and planting depth on seedling miss index.

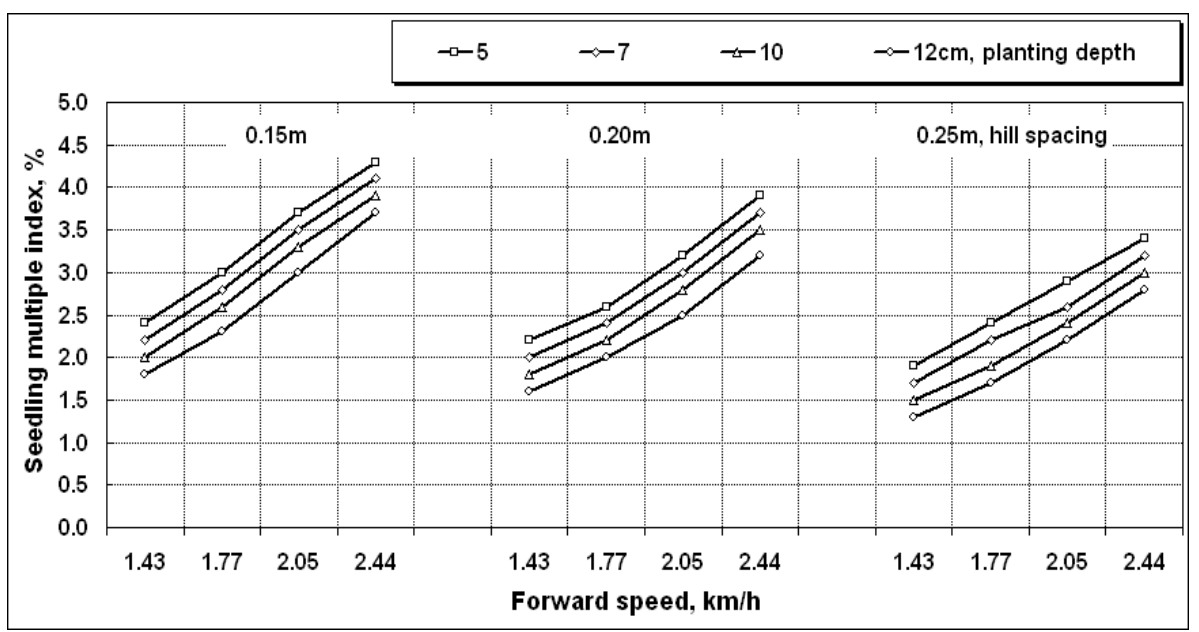

Fig. 4: Effects of forward speed, hill spacing and planting depth on seedling multiple index. 


\section{The quality of feed index:}

Plants which are transplanted with closer spacing they have to compete among themselves for the soil moisture, sun light and nutrients. But the seedlings which are transplanted at a wider spacing are able to receive all inputs at optimum level and can be able to reproduce their potential yield. Data in Fig. 5 indicates that, the quality of feed index was decreased with increasing forward speed, while it was increased with increasing both of hill spacing and planting depth. Also, from previous results, it can be noticed that hill spacing was very important factor affected on the quality of feed index. Also, minimum the quality of feed index of $89.6 \%$ was recorded with forward speed of $2.44 \mathrm{~km} / \mathrm{h}$, hill spacing of $0.15 \mathrm{~m}$ and planting depth of $5 \mathrm{~cm}$.

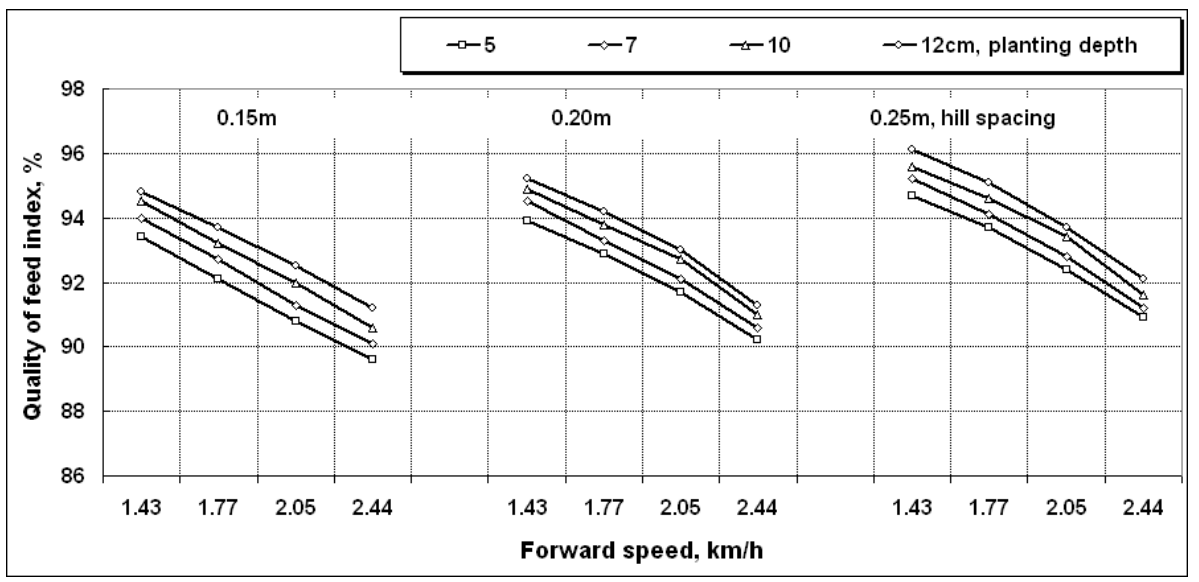

Fig. 5: Effects of forward speed, hill spacing and planting depth on the quality of feed index.

\section{Productivity and losses in productivity due to missing seedling:}

Results indicated that, final crop productivity was decreased with increasing of forward speed while it was increased with increasing both of hill spacing and planting depth. Also, losses in productivity due to missing seedling were increased by increasing both of forward speed and hill spacing while; it was decreased with increasing planting depth as shown in Fig. 6. Results also found that, maximum productivity was $7.61 \mathrm{kentar} / \mathrm{fed}$ recorded at forward speed of $1.43 \mathrm{~km} / \mathrm{h}$, hill spacing of 
$0.25 \mathrm{~m}$ and planting depth of $5 \mathrm{~cm}$ while, minimum losses in productivity due to missing seedling of $0.163 \mathrm{kantar} / \mathrm{fed}$ was recorded at forward speed of $1.43 \mathrm{~km} / \mathrm{h}$, hill spacing of $0.25 \mathrm{~m}$ and planting depth of $12 \mathrm{~cm}$. From the above it is clear that, forward speed was more influential factor on losses in productivity due to missing seedling. From crossing carves of total productivity and total losses in productivity results showed that the optimum operations condition were at using forward speed of $1.77 \mathrm{Km} / \mathrm{h}$, planting depth of $10 \mathrm{~cm}$ and hill spacing of $0.20 \mathrm{~m}$, respectively. This condition recorded total productivity of $7.31 \mathrm{kantar} / \mathrm{fed}$ and total losses in productivity of $0.226 \mathrm{kantar} / \mathrm{fed}$.

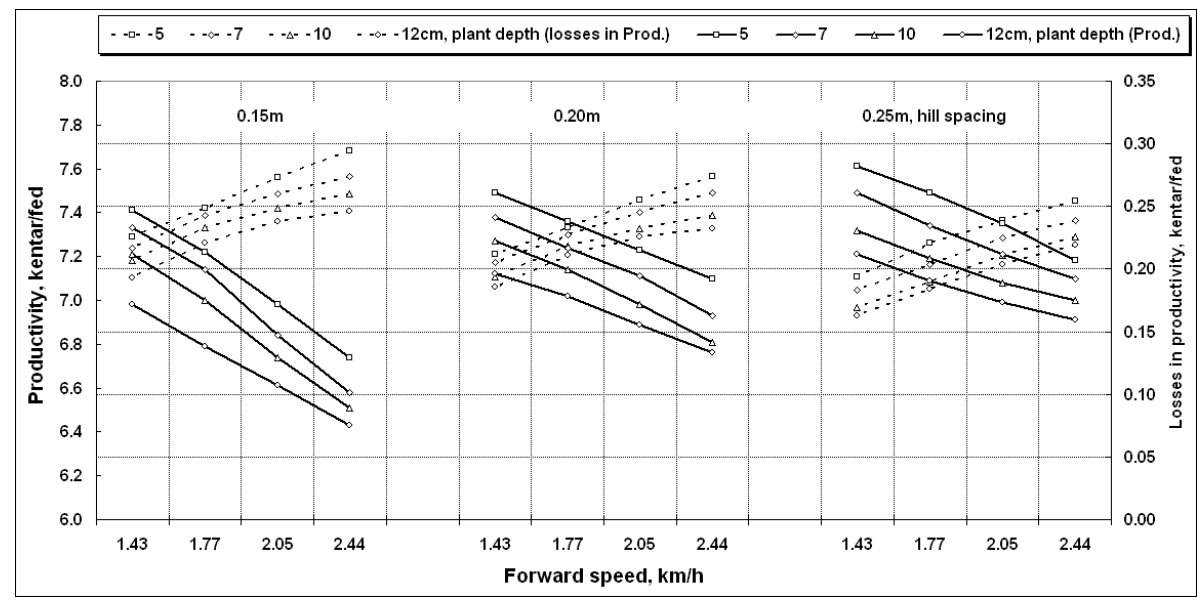

Fig. 6: Effects of forward speed, hill spacing and planting depth on total productivity and losses in productivity.

\section{B- Characteristics of two used cotton genotypes:}

After selecting the optimum conditions for operating transplanting machine during 2013 on cotton variety G86. We achieved planting manually area using the same optimum mechanical planting specifications were used the spacing between rows on the distance of $0.76 \mathrm{~m}$, hill spacing of $0.15 \mathrm{~m}$ and planting depth of $7 \mathrm{~cm}$. And so to compare the impact of transplanting method of (mechanically - manually) on some of plants traits of the grown variety and also to study the impact of transplanting method on the technological qualities of cotton variety user. 


\section{The effects of the interaction between planting methods on cotton genetic traits:}

The results in Table 3 showed the comparison between the two various transplanting method(mechanical and manual) on the traits characteristics of the cotton variety G86 that all contributions traits under study such as h. first fruit, seed cotton yield, boll weight, lint percent seed index and lint index were of the highest values with the use of mechanical transplanting comparing with manual transplanting method.

Table 3: Effects of the mechanical and manual transplanting method on genetic traits of cotton G86 variety

\begin{tabular}{|l|c|c|c|c|c|c|}
\hline Method & $\begin{array}{c}\text { h. first } \\
\text { fruit, } \\
\mathrm{cm}\end{array}$ & $\begin{array}{c}\text { seed cotton } \\
\text { yield, } \\
\text { kentar/fed. }\end{array}$ & $\begin{array}{c}\text { boll } \\
\text { weight } \\
\text {,gram }\end{array}$ & $\begin{array}{c}\text { lint } \\
\text { percent, } \\
\%\end{array}$ & $\begin{array}{c}\text { lint } \\
\text { index }\end{array}$ & $\begin{array}{c}\text { seed } \\
\text { index }\end{array}$ \\
\hline Manual & 6.00 & 8.72 & 2.70 & 41.97 & 11.59 & 9.77 \\
\hline Mechanical & 6.00 & 10.61 & 2.79 & 43.90 & 14.99 & 10.24 \\
\hline
\end{tabular}

\section{The effects of the interaction between transplanting methods on seed cotton technological qualities:}

Results in Table 4 summarized the effect of interaction between mechanical and manual transplanting on the technological characteristics of the cotton variety G86 that all contributions traits under study such as $50 \%$ span length, 2.5\% span length, strength, microniere reading, elongation, uniformity ratio, reflectance and yellowness were of the highest values with the use of mechanical transplanting compared with manual transplanting method. This shows the comparative advantage to use of mechanical transplanting method compared with manual transplanting method and this excellence was a return to the regular distribution of plants in the field when using mechanical transplanting method compared with manual transplanting method, which was given the opportunity for each plant to grow regularly and thus distinguish characteristics of technological output of cotton. 
Table 4: Seed cotton G86 variety technological qualities resulting from mechanical and manual transplanting method.

\begin{tabular}{|l|c|c|c|c|c|c|c|c|}
\hline Method & $\begin{array}{c}50 \% \\
\text { span } \\
\text { length }\end{array}$ & $\begin{array}{c}2.5 \% \\
\text { span } \\
\text { length }\end{array}$ & $\begin{array}{c}\text { Stren } \\
\text {-gth }\end{array}$ & $\begin{array}{c}\text { Micro } \\
\text { niere }\end{array}$ & $\begin{array}{c}\text { Elong- } \\
\text { ateion }\end{array}$ & $\begin{array}{c}\text { unifor- } \\
\text { mity }\end{array}$ & $\begin{array}{c}\text { Refle- } \\
\text { ctance }\end{array}$ & $\begin{array}{c}\text { Yello- } \\
\text { wness }\end{array}$ \\
\hline Manual & 15.53 & 32.35 & 28.91 & 5.29 & 8.39 & 47.89 & 74.10 & 7.39 \\
\hline Mechanical & 17.00 & 32.58 & 28.91 & 5.31 & 8.49 & 51.01 & 73.96 & 7.43 \\
\hline
\end{tabular}

\section{CONCLUSION}

\section{The characteristics conclusion could be summarized as follow:}

- The optimum operation condition for modifying transplanter was recorded at forward speed of $1.77 \mathrm{~km} / \mathrm{h}$, hill spacing of $0.20 \mathrm{~m}$ and planting depth of $10 \mathrm{~cm}$ at this condition results recorded productivity of $7.31 \mathrm{kantar} / \mathrm{fed}$ and total losses in productivity of $0.226 \mathrm{kantar} / \mathrm{fed}$.

Maximum of effective field capacity was $0.711 \mathrm{fed} / \mathrm{h}$ was recorded at forward speed of $2.44 \mathrm{~km} / \mathrm{h}$, hill spacing of $0.25 \mathrm{~m}$ and planting depth of $5 \mathrm{~cm}$. While, the maximum field efficiency of $80.1 \%$ recorded at forward speed of $1.43 \mathrm{~km} / \mathrm{h}$, hill spacing of $0.25 \mathrm{~m}$ and planting depth of $5 \mathrm{~cm}$.

4 Seedling miss index and seedling multiple index and the quality of feed index were increased with increasing both forward speed and hill spacing while, it was decreased with increasing planting depth.

( Maximum productivity of $7.61 \mathrm{kantar} / \mathrm{fed}$ was recorded at forward speed of $1.43 \mathrm{~km} / \mathrm{h}$, hill spacing of $0.25 \mathrm{~m}$ and planting depth of $5 \mathrm{~cm}$.

( Mechanical transplanting cotton seedlings increased both seed cotton yield and lint cotton yield with used genotype of G86.

( Mechanical transplanting cotton seedlings increased all seed cotton technological properties compared with manual transplanting method. 


\section{REFERENCES}

Abbas , A.M. (1981). Effect of some agricultural practices on growth and yield of cotton .M.Sc.Thesis ,Fac.Ag.,Al-Azhar Univ., Cairo „Egypt, 62-73.

Abou-Zeid, H.M; H.A. Abd El-Aali; A.A. Darwish and W.M. El-Shazly (1995). Transplanting and seedling age influence on agronomic performance of Giza cotton cultivar. Annuals Ag. Sci, Ain Shams Univ., Cairo, 40(2): 609-619.

ASTM (1989). Designatians:D,(1684-96). American society for testing and materials. Standards of Textile Testing and Materials. Society, Philadelophia, USA.

ASTM, Standards (1984). Designations: 1445-75. American society for testing and materials. Standards of textile testing and materials. The society, philadelaphia, USA.

Dong, H.Z.; Zhang, D.M.; Tang, W.; Li, W.J. and Li, Z.H. (2005). Effects of planting system, plant density and flower removal on yield and quality of hybrid seed in cotton. Field Crops Res., 93: 74-84.

El-Fowal, Y.A.A. (1996). A study on possibilities of mechanical wheat transplanting. M.Sc. Thesis, Fac. Ag., Al-Azhar Univ., Egypt.

El-Sahrigi, A.F., A.S., Kamel and S.I., El-Khatib (2001). A study on mechanization of cotton transplanting. Egypt J. Ag. Res. 79 ( 2): 740-756.

EL-Sayed. E.A.S. (1992). Effect of transplanting on growth and yield of cotton. M. Sc. Th., Tanta Univ., Egypt.

Greer, N.W.; K.S., Mclean; Kloepper, J.W. (2003). Potential of cotton transplants and rhizobacteria to shorten the growing season. In: Proceedings of the Beltwide Cotton Conference. 6(2):, 13-16.

Hamed, S.A., M.A.Ali , A.M. khalifa and A.M. Ismail (1993). A manual Feeding rice transplanter. J. Ag. Sci., Mansoura Univ. 8(1): 72- 80.

Hassan, I.S.M.; H.B. Abou-Tour and S.M. Seyam (2006). Evaluation and stability parameters of the hybrid G.84 (G.74×G.68) and four 
Egyptian extra-long staple cotton cultivars grown at North Delta, Egypt. J. of Appl. Sci. 21(8):59-73.

Herb, S.K., H.A. Abdell-Mawal and G.M. Salama (1993). Comparison between mechanichal and manual transplanting of tomato. Minia J. of Ag. Res. 15 (1): 361-375.

Imam, G.M.I. (1991). A study of some factors affecting yield and fiber properties in cotton. Ph.D. Thesis, Fac. Ag., Ain Shams Univ., Cairo, 113-120.

Karve, A.D. (2003). High yield of rainfed cotton through transplanting. Curr. Sci. 84 : 974-975.

May, O.L. and B.C. Bridges, Jr. (1995). Breeding cottons for conventional and late planted production systems. Crop Sci., 35: 132-136.

Radwan., F.E. (1988). Evaluation of some methods of cotton planting in relation to their effect on yield and quality .M.Sc. Thesis, Fac. Ag., Moshtohor, Zagazig Univ., Egypt, 72-77.

Salama, G.M.; A.M. Youssef and S.S.A. Farge (1995). Tomato plant growth and productivity as affected by method transplanting. Vegetable Res. Section. Hort. Res. Inst.. Ag. Res. Conter. Cairo, Egypt, 22 (2): 109-115.

Sales, E.; R., Kanhonou and C., Baixauli (2006). Sowing date, transplanting, plant density and nitrogen fertilization affect indigo production from Isatis species in a Mediterranean region of Spain. Ind. Crops Prod. 23 :29-39.

Self-El-Nasr, F.M., Z.M. Attia, H.E. Khalil, S.A.A. Shams and A.S. Kamel, 1996. Growing long duration winter crop in cotton rotation. Annuals of Agricultural Sci. Moshtohor, 34: 501-512.

Sherif, M.N.; M.S.M, Selim and A.S., Kamel (1995). Studies on some factors affecting seed and fiber properties of transplanted cotton. Annuals of Ag. Sci. Moshtohor, 33: 647-657. 
Srivastava A. K.; C.E. Goering and R.P. Rohrbach (1995). Engineering principles of agricultural machine. ASAE Textbook Number $b$. American Society of Agricultural Engineers, 295 Niles Road, St.joseph, Michigan 49085-9659, USA.

Waddle, B.A. (1993). In: Cotton ,Ed. R. J. Kohel and C.F. Lowis, American Society of Agronomy, Crop Science Society of America and Soil Science Society of America: Madison, Wisconsin, USA.

\section{الملخص العربي \\ تأثير تقنية الثتل الميكانيكي على الإنتاجية لصنف القطن جيزة 1 القئ محمد عبد الله إبراهيم حسن' ومحمد عبد الحميد بسيونى ' وعاطف عزت اليمانيץ}

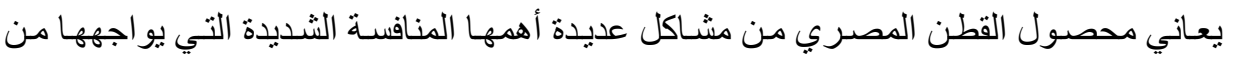
المحاصيل الأخرى. و يتم زر اعة القطن بالثتلات بهدف تقصير موسم نمو القطن لتو فير أو تقليل

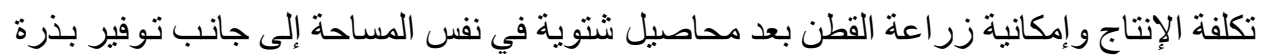
القطن و المحافظة على نقاوة الصنف وخفض نسبة الإصابات المبكرة و المتأخرة ، لذلك فقد كانت

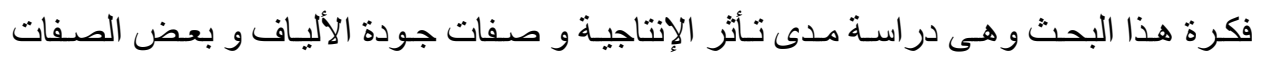

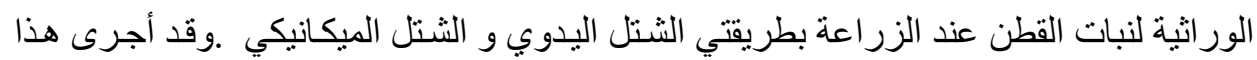
البحث باستخدام آلة شتل أمريكية الصنع ماركة Holland لتناسب شتنل القطن وتم تقيّمي أدائها

$$
\text { باستخدام المتغير ات التالية: }
$$

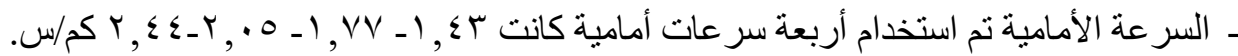

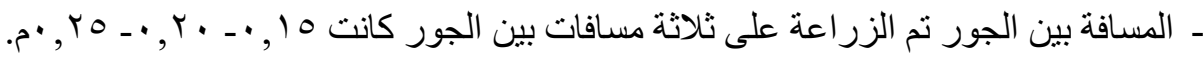

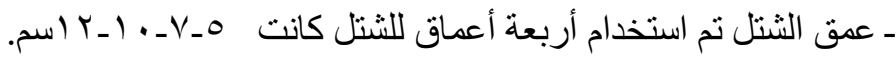

ـ طريقة الزر اعة تم استخدام طريقتين (طريقة الشتل الميكانيكية - طريقة الشتل اليدوي).

\section{وتم الحصول على النتائج التالية:}

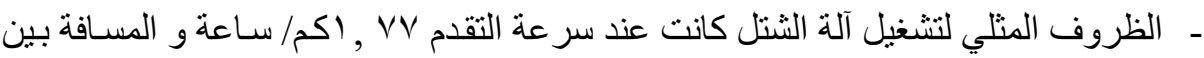

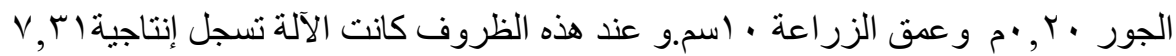

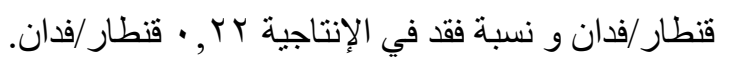

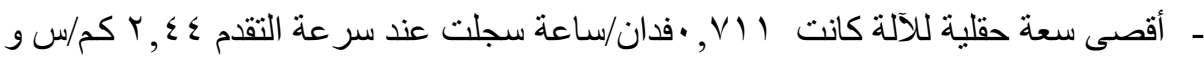

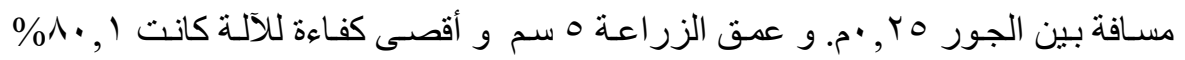

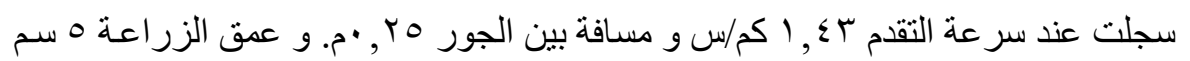

$$
\text { 'باحث و باحث أول بمعهد بحوث الهندسة الزراعية ـ مركز البحوث الزراعية ـ الجيزة - مصر. }
$$




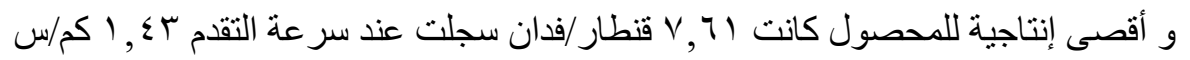

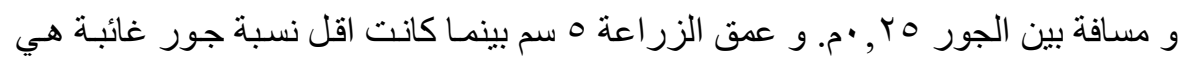

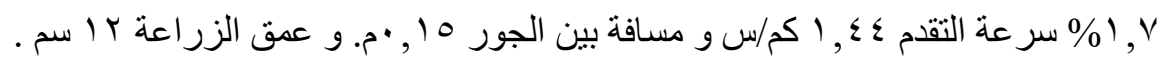

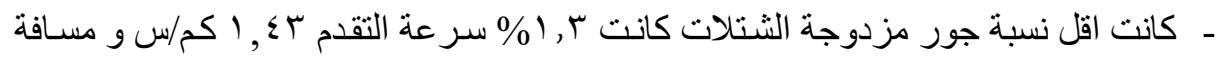

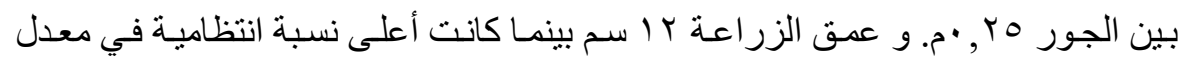

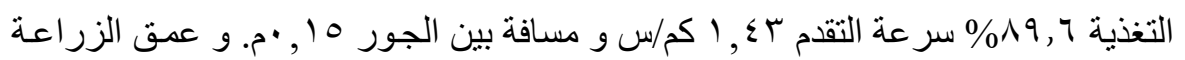
0 ـ ـ طريقـة الثـتل الميكانيكي كانت لهـاتـأثير مباشـر على جـودة الصـفات النباتيـة للمحصـول مقارنة بطريقة الزر اعة بالثنت اليدوي.

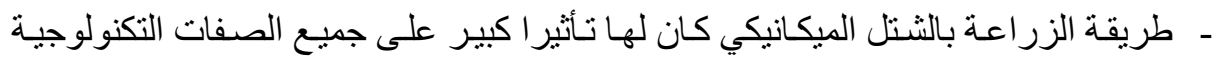
للقطن الزهر مقارنة مع طريقة الزراعة بالشتنل اليدوي . 